\title{
Bacteriological and serological study on synovial Fluid in septic arthritis patients
}

\author{
Shehab Ahmed Lafi ; Omaima T.M. Al-Mashhadani and Waleed I. Al-Obaidi \\ Microbiology Department College of Medicine Al-Anbar University, \\ Ramadi ,West of Iraq. \\ Email-shehab_58@yahoo.com
}

\begin{abstract}
ABCTRAT
\section{Background}

Septic arthritis is the microbial infection of the joint constituents. Various microorganisms can be involved in arthritis like bacteria, viruses, fungi and other microorganisms like Mycoplasma. bacterial pathogens are the most significant.
\end{abstract}

Aims of the study:

1- To study the most important macroscopic and microscopic characters of synovial fluid samples in patients with septic arthritis.

2-Iisolation and identification of bacteria involved in septic arthritis.

3- To perform some serological tests for patients with septic arthritis, like (CRP, ASOT, RF).

4- To study of white blood cell count, sugar and protein in synovial fluid of patients with septic arthritis.

\section{Materials \& Methods:}

One hundred patients from both sexes and different age groups (1-80) years were included in this study. They were attending Department of Orthopedics and Joints Diseases in Ramadi General Hospital and Private Clinics of Orthopedics and Joints diseases during the period from May 2008 to January 2009. synovial fluid aspirates and blood specimens were taken from each one, these specimens were manipulated soon following bacteriological ,serological and biochemical required tests.

\section{Results:}

Twenty five (25) patients were suffering from septic arthritis and seventy five (75) of them were affected with aseptic type, males represented $67 \%$ of total patients.

The highest rate of arthritis was found within age group (19-49) years old while septic arthritis was higher within Age group (50-80) years old patients. Synovial fluid from 22 patients showed poor mucin while that from 23 patients had low viscosity and 10 patients showed purulent synovial fluid. Gram positive bacteria were most common pathogens, regarding single infections Staphylococcus aureus took the first rank of isolation (11 isolates) with (55\%) followed by Staphylococcus epidermidis and Escherichia coli. Other bacteria were showing lower rate of isolation. patients with septic arthritis were showing more WBCs in their synovial fluid. The mean values of C- reactive protein within age groups (19-49) and (50-80) years of septic arthritis were $26 \mathrm{mg} / \mathrm{L}$ and $27 \mathrm{mg} / \mathrm{L}$ respectively. (17) patients with aseptic arthritis and one patient of septic arthritis showed positive rheumatoid factor test.

One child and another one patient within the same age group (19-49) years old were showed positive titer of ASOT test.

Mean sugar values in synovial fluid of septic type were lower than that of a septic type while all patients were showing higher protein values in synovial fluid.

Keywords: Septic arthritis, Bacterial arthritis, Arthritis 


\section{INTRODUCTION}

The joint cavity is usually sterile space with synovial fluid and cellular matter including few White blood cells. Brusch, L. J., (2005).

Septic arthritis is the inflammation of joint constituents. It means the infection of the lining membrane of the joint called the synovium. The knee is the most commonly involved joint accounting for about $50 \%$ of the cases. Livolsi, V. A., et al. (1993).

Various microorganisms may be involved in arthritis like bacteria, viruses, fungi and other microorganisms like Mycoplasma. Although any infectious agent may cause arthritis, bacterial pathogens are the most significant. Dale, C. D., and Federman, D. D. (2003).

The most common mode of spread of septic arthritis is haematogenous with the predisposing factors like intravenous drug use, presence of indwelling catheters and immunocompromised status. The other predisposing conditions are rheumatoid arthritis, gout or osteoarthritis. Ryan, M. J. et al. (1997).

Gram positive and gram negative bacteria are imposed in septic arthritis like Staphyllococcus aureus, Staphylococcus epidermidis, pyogenes, Neisseria gonorrhoeae, gram negative bacilli, and Myco tuberculosis. Ryan, M. J. et al. (1997) and Dickie, A. S. (1986).

Septic arthritis must be diagnosed quickly and treated with antibiotics, surgery is more effective especially if pus is thick then a repeat aspiration may be required depending on the clinical signs and symptoms. Laurent, R. and Gleeson, R. (2000). In our community this conflict still needs more investigation so this study is devoted.

\section{MATERIALS AND METHODS}

Synovial fluid aspirate was taken from (100) patients attending the Department of Orthopedics in Ramadi General Hospital and Private Orthopedic Clinics during the period extended from May 2008 to January 2009 .Synovial specimens were taken by senior Orthopedist from patients of both sexes and age groups (1- 80) years. Synovial fluid was a spirited and transported to the lab in a cool box as soon as possible for processing physical characters (color, viscosity) were reported soon after aspiration.

Three ml of venous blood were taken aseptically from each patient and transferred to clean and dry plane tube (without anticoagulant) for serum collection after clotting and centrifuged the blood at $2500 \mathrm{rpm}$ for 5 minutes pooled serum was kept in Epindruf tubes at $-20{ }^{\circ} \mathrm{C}$. to be used.

\section{Synovial fluid investigation:}

Physical characters of Synovial fluid (color, viscosity), Biochemical tests on synovial fluid include (Mucin clot test, Sugar and protein estimation and PH) were performed following Davidson, I. and Henry, B. J. (1974).

Bacteriological study was done following Washington et al. 2006, by direct smears examination stained with Gram stain and zihel Nelsen stain and inoculation aerobically on Blood agar and MacConkey agar plates and incubated at $37 \circ \mathrm{C}$ for 24 hours. Inoculated chocolate agar plates were incubated under $5-10 \%$ of $\mathrm{CO}_{2}$. blood agar plates were incubated anaerobically using anaerobic Gaspack system Oxoid (France )for $48 \mathrm{hr}$ at $37^{\circ} \mathrm{C}$. Bacterial identification by using different biochemical tests as (Oxidase test, Catalase test, Coagulase test, Api system (Api 20 E Aerobic, and Api system (Api 20 Anaerobic). Serological tests in this 
work included C- Reactive protein test (CRP), Antistreptolysine $\mathrm{O}$ titer test (ASOT) and Rheumatoid factor (RF) test, white blood cell count was done for Synovial fluid samples following Davidson, I. and Henry, B. J. (1974).

\section{Statistical analysis}

Data qualitative of this study had been analyzed statistically using Chi (X2) square test to find the significance of probability level (P) value of the increase or decrease for all studied factors. Data had been analyzed statistically using SPSS program.

\section{RESULTS}

One hundred patients from both sexes and different age groups were included in this study. Twenty five (25) of them were suffering from septic arthritis and (75) were suffering from other types of arthritis. Regarding sex distribution, males were showing higher rate of arthritis than females (table 1) (table 2).

(Table -1) Distribution of age and sex among patients with arthritis.

\begin{tabular}{||c|c|c|c|c|c|c||}
\hline \multirow{2}{*}{$\begin{array}{c}\text { Age groups } \\
\text { (Years) }\end{array}$} & \multicolumn{2}{|c|}{ Males } & \multicolumn{2}{c|}{ Females } & \multicolumn{2}{c||}{ Total } \\
\cline { 2 - 7 } & No & $\%$ & No & $\%$ & No & $\%$ \\
\hline \hline$\leq \mathbf{1 8}$ & 6 & 85.7 & 1 & 14.3 & 7 & $7 \%$ \\
\hline $\mathbf{1 9 - 4 9}$ & 38 & 60.3 & 25 & 39.7 & 63 & $63 \%$ \\
\hline $\mathbf{5 0 - 8 0}$ & 23 & 76.6 & 7 & 23.4 & 30 & $30 \%$ \\
\hline Total & 67 & $67 \%$ & 33 & $33 \%$ & 100 & $100 \%$ \\
\hline
\end{tabular}

(Table -2) Distribution of patients according to the type of arthritis.

\begin{tabular}{||c|c|c|c|c|c|c||}
\hline \multirow{2}{*}{$\begin{array}{c}\text { Age } \\
\text { Groups } \\
\text { Years) }\end{array}$} & \multicolumn{3}{|c|}{ Septic arthritis } & \multicolumn{2}{c|}{ Aseptic arthritis } & \multicolumn{4}{c||}{ Total } \\
\cline { 2 - 7 } & No & $\%$ & No & $\%$ & No & $\%$ \\
\hline$\leq 18$ & 0 & 0.0 & 7 & 9.3 & 7 & 7 \\
\hline $\mathbf{1 9 - 4 9}$ & 11 & 44 & 52 & 69.3 & 63 & 63 \\
\hline $\mathbf{5 0 - 8 0}$ & 14 & 56 & 16 & 21.4 & 30 & 30 \\
\hline Total & 25 & $100 \%$ & 75 & $100 \%$ & 100 & $100 \%$ \\
\hline
\end{tabular}

Majority of specimens (23) out of (25) were showing low viscosity with low mucinase activity and all of them were turbid, $\mathrm{pH}$ of samples range was between (6-7) (table 3). Out of 25 gram stained smears16 smears were showing gram positive organisms, while 9 of them were gram negative organisms, all specimens showed negative AFB test. 
(Table -3) Physical characters and pH of synovial fluid in septic arthritis.

\begin{tabular}{||l|c|c||}
\hline \multicolumn{2}{|c|}{$\begin{array}{c}\text { Physical characters of synovial } \\
\text { Fluid }\end{array}$} & No. of samples \\
\hline \hline 1- Mucin clot & poor & 22 \\
& Moderate-poor & 2 \\
& Moderate & 1 \\
\hline 2- Viscosity & High & 2 \\
& Low & 23 \\
\hline 3- PH & 6 & 13 \\
& 7 & 12 \\
\hline 4- Colour & Turbid yellow & 4 \\
& Purulent & 10 \\
& Turbid & 6 \\
& Gray & 5 \\
\hline
\end{tabular}

Regarding single infections Staphylococcus aureus which took the first rank of isolation (11 isolate) with (55\%) followed by Staphylococcus epidermidis and Escherichia coli (10\%) for each one, other species, Streptococcus pyogenes, Pseudomonas
Peptostreptococcus sp., Klebsiella sp, and Neisseria gonorrheae, were showing (5\%) equally in (table 5). Staphylococcus aureus showed the highest rate of mixed isolation with other bacterial types like with $E$ coli (40\%), with S. epidermidis, and Proteus sp. (20\%) for each (in table 4$)$.

(Table -4) Types and numbers of mixed bacterial isolates in patients with septic arthritis.

\begin{tabular}{|c|c|c||}
\hline \multicolumn{1}{|c|}{ Types of M.O } & No of isolates & $\%$ \\
\hline \hline $\begin{array}{l}\text { Staphylococcus aureus and } \\
\text { Staphylococcus epidermidis }\end{array}$ & 1 & 20 \\
\hline $\begin{array}{l}\text { Staphylococcus aureus and } \\
\text { Escherichia coli }\end{array}$ & 2 & 40 \\
\hline $\begin{array}{l}\text { Klebsiella and Pseudomonas } \\
\text { aeruginosa }\end{array}$ & 1 & 20 \\
\hline $\begin{array}{l}\text { Staphylococcus aureus and } \\
\text { proteus species }\end{array}$ & 1 & $100 \%$ \\
\hline \multicolumn{1}{|c|}{ Total } & 5 & 20 \\
\hline
\end{tabular}

White blood cells mean values in synovial fluid specimens from patients with septic arthritis showed higher values than aseptic type (table 5). The mean values of $\mathrm{C}$ - reactive protein within age groups (19-49) and (50-80) years of septic arthritis were 26 $\mathrm{mg} / \mathrm{L}$ and $27 \mathrm{mg} / \mathrm{L}$ respectively, while the mean values for individuals from the same age groups suffering from aseptic arthritis were 21 and $16 \mathrm{mg} / \mathrm{L}$ respectively. 
(Table -5) WBCs values in synovial fhuid of patients with septic and aseptic arthritis.

\begin{tabular}{||c|l|l||}
\hline $\begin{array}{c}\text { Age groups } \\
\text { Years) }\end{array}$ & $\begin{array}{l}\text { WBCs cell/cmm3 in } \\
\text { Septic arthitis }\end{array}$ & $\begin{array}{l}\text { WBCs cell/cmm3 in } \\
\text { Aseptic arthritis }\end{array}$ \\
\hline \hline$\leq 18$ & $\begin{array}{l}\text { Rang 0 } \\
\text { Mean 0 }\end{array}$ & $\begin{array}{l}\text { Rang (8000-45000) } \\
\text { Mean (15714) }\end{array}$ \\
\hline$(19-49)$ & $\begin{array}{l}\text { Rang (45000-90000) } \\
\text { Mean (58636.36) }\end{array}$ & $\begin{array}{l}\text { Rang (1100-50000) } \\
\text { Mean (8382.692) }\end{array}$ \\
\hline $\mathbf{( 5 0 - 8 0 )}$ & $\begin{array}{l}\text { Rang (60000-90000) } \\
\text { Mean (73214.29) }\end{array}$ & $\begin{array}{l}\text { Rang (1000-20000) } \\
\text { Mean (5631.25) }\end{array}$ \\
& & \multicolumn{2}{|l}{} \\
\hline
\end{tabular}

* Number of patients with septic arthritis $=$ o.

Patients within aseptic arthritis groups were showing more positive results of Rheumatoid factor than those suffering from septic type. While one patient from each septic and aseptic type of arthritis were showing high ASOT result (table 6).
Biochemical investigations of synovial fluid in patients with septic arthritis showed lower mean sugar value in there synovial fluid while all patients were showing higher protein values in Synovial fluid (table-7).

(Table -6) CRP, RF, ASOT values in patients with septic and aseptic arthritis.

\begin{tabular}{|c|c|c|c|c|c|c|}
\hline \multirow{2}{*}{$\begin{array}{c}\text { Age } \\
\text { group } \\
\text { (years) }\end{array}$} & \multicolumn{3}{|c|}{ Septic arthritis } & \multicolumn{3}{|c|}{ Aseptic arthritis } \\
\hline & $\begin{array}{c}\text { CRP } \\
\mathbf{M g} / \mathbf{L}\end{array}$ & $\begin{array}{c}\mathbf{R F} \\
\mathbf{I U} / \mathbf{m l}\end{array}$ & $\begin{array}{l}\text { ASOT } \\
\text { IU/ml }\end{array}$ & $\begin{array}{l}\text { CRP } \\
\mathbf{M g} / \mathbf{L}\end{array}$ & $\begin{array}{c}\mathbf{R F} \\
\mathbf{I U} / \mathbf{m l}\end{array}$ & $\begin{array}{l}\text { ASOT } \\
\text { IU/ml }\end{array}$ \\
\hline$\leq \mathbf{1 8}$ & 0 & 0 & 0 & $\begin{array}{l}\mathrm{R}(12-36) \\
\mathrm{M}(17) \\
(7 \text { cases })\end{array}$ & $\begin{array}{l}\text { (2 case) } \\
*\end{array}$ & $\begin{array}{l}\text { (onecase) } \\
*\end{array}$ \\
\hline 19-49 & $\begin{array}{l}\mathrm{R}(18-36) \\
\mathrm{M}(26) \\
\text { (11 case) }\end{array}$ & $\begin{array}{l}\text { (onecase) } \\
*\end{array}$ & $\begin{array}{l}\text { (onecase) } \\
*\end{array}$ & $\begin{array}{l}\mathrm{R}(12-42) \\
\mathrm{M}(21) \\
(52 \text { case })\end{array}$ & $\begin{array}{c}\mathrm{R}(16-128) \\
M(38) \\
(15 \text { case })\end{array}$ & 0 \\
\hline $50-80$ & $\begin{array}{l}\mathrm{R}(18-36) \\
\mathrm{M}(27) \\
(14 \text { case) }\end{array}$ & 0 & 0 & $\begin{array}{l}\mathrm{R}(12-18) \\
\mathrm{M}(16) \\
(16 \text { case })\end{array}$ & 0 & 0 \\
\hline
\end{tabular}

${ }^{*} \mathrm{RF}$ value in septic arthritis $(64 \mathrm{JU} / \mathrm{ml}), \mathrm{ASOT}$ value in septic arthritis $(800 \mathrm{IU} / \mathrm{ml})$

* RF values in aseptic arthritis $(32 \mathrm{IU} / \mathrm{ml})$, ASOT value in aseptic arthritis $(400 \mathrm{IU} / \mathrm{ml})$

(Table- 7) Sugar and protein results from patients with septic and aseptic arthritis.

\begin{tabular}{|c|c|c|c|c|}
\hline \multirow{2}{*}{$\begin{array}{c}\text { Age } \\
\text { groups } \\
\text { (years) }\end{array}$} & \multicolumn{2}{|c|}{ Septic arthritis } & \multicolumn{2}{|c|}{ Aseptic arthritis } \\
\hline & Sugar(mg/dl) & $\operatorname{Protein}(g / L)$ & Sugar(mg/dl) & Protein $\left(\mathrm{g}^{\prime} / \mathrm{L}\right)$ \\
\hline$\leq \mathbf{1 8}$ & No any case & No any case & $\begin{array}{l}\mathrm{R}(36-90) \\
\mathrm{M}(68) \\
\pm \mathrm{SD}(20.16)\end{array}$ & $\begin{array}{l}\mathrm{R}(19-45) \\
\mathrm{M}(28) \\
\pm \mathrm{SD}(9.47)\end{array}$ \\
\hline 19-49 & $\begin{array}{l}\mathrm{R}(20-32) \\
\mathrm{M}(26) \\
\pm \mathrm{SD}(3.12)\end{array}$ & $\begin{array}{l}\mathrm{R}(40-56) \\
\mathrm{M}(42) \\
\pm \mathrm{SD}(5.01)\end{array}$ & $\begin{array}{l}\mathrm{R}(36-95) \\
\mathrm{M}(63) \\
\pm \mathrm{SD}(13.83)\end{array}$ & $\begin{array}{l}\mathrm{R}(13-59) \\
\mathrm{M}(28) \\
\pm \mathrm{SD}(9.00)\end{array}$ \\
\hline $50-80$ & $\begin{array}{l}\mathrm{R}(20-30) \\
\mathrm{M}(27) \\
\pm \mathrm{SD}(3.86)\end{array}$ & $\begin{array}{l}\mathrm{R}(31-62) \\
\mathrm{M}(48) \\
\pm S D(8.76)\end{array}$ & $\begin{array}{l}\mathrm{R}(46-95) \\
\mathrm{M}(70) \\
\pm \mathrm{SD}(10.38)\end{array}$ & $\begin{array}{l}\mathrm{R}(20-48) \\
\mathrm{M}(26) \\
\pm \mathrm{SD}(4.97)\end{array}$ \\
\hline
\end{tabular}




\section{DISCUSSION}

Arthritis is multifactorial disorder and one of these factors is infection so we found $25 \%$ of cases were septic type. Livolsi, V. A. (1993). Males showed the highest rate $(67 \%)$ of arthritis among all studied groups .This was ought to the physiological status of males and their exposure to the Occupational risk. This result was in agreement with (Geirsson, et al., 2008), who found that $62 \%$ of males were affected with arthritis. But this result was disagree with 10 (Caksen and his Colleagues, 2000), who found that $22(55 \%)$ were males. Wars in Iraq increased the risk of trauma and injuries for males more than females in this category. Although arthritis was more frequent among aged individuals due to the high risk factors of arthritis among them but we found the highest rate of arthritis within age group (19-49) years.

This might be due to many factors like sampling method which was unable as to get samples from aged individuals because of restrictions and difficulty of mobility of such group to reach clinics due to bad traffic and security in this city because of risky war or other risk factors like habitual, familial, nutritional, occupation of individuals that predispose arthritis among them early. This was in agreement with (Al-Baiatti, 2004), who found that the highest rate of arthritis was in (35-40) age group. Septic arthritis was not recorded in children in this study; this was absolutely due to sampling method. So we can not match this observation with other references who recorded different rates of septic arthritis among children.

In this study the highest rate of septic arthritis (56\%) was found within age group $(50-80)$ years as this age group often has Preexisting Medical Conditions (e.g., Diabetes mellitus) and other age related joint disorders. Septic arthritis almost occurs in the extremities of age, despite in depth research into the pathophysiology and treatment of septic arthritis, the morbidity and mortality are still significant. Vincent, G.M. and Amirault, JD. (1990). Gavet, F. et al. (2005).

High rate of septic arthritis among patients over 50 years old was in agreement with (Brusch 2005), who found the highest percentage of cases among over 50 years patients.

Intra articular infections lead to many pathological and physiological changes which cause shift of synovial fluid physical and chemical characters such as decreased viscosity, decreased mucinase activity, abnormal color, pus tinged, and that was observed in this study, Davidson, I. and Henry, B. J. (1974). Mucin clot test in most of the samples was poor degree due to the enzymes released from inflamed cells, Gaffney, K. et al. (1995). Viscosity test used as an indicator of disease activity, low degree of viscosity character due to inflammatory fluid the clump of hyaluronate-protien complex (mucin) will fragment easily reflecting the loss of integrity of hyaluronan, Sweiss, N. et al. (2009). Turbid color of synovial fluid was due to the number of WBCs and pus cells which determines the turbidity of inflammatory SF, also lipids, crystals and debris that accumulates in destructive forms of arthritis. Gatter, R. A. (1984). Low PH of studied Synovial fluid specimens was due to inflammatory processes and sepsis, which leads to increase hydrogen ions $(\mathrm{H}+)$ via lactate enzyme release in Synovial fluid, Dorwart, B. B. and Schumacher, H. R. (1975).

Microscopical examination of Synovial fluid specimens showed negative acid fast bacilli results during direct smear examination with zehil Nelssen stain .This might be due to sampling from non tuberculosis patients. Staphylococcus aureus took the first rank of isolation (55\%), 11 out of 20 cases bacterial isolates, this was in agreement with the ratio observed by many references like. Geirsson, J. A. et al. (2008). \& Le Dantec, L. F. et al. (1996). and AlMashhadani S. S.(2003).

Higher rate of $S$. aureus isolation was observed by Munoz, G. and Raycraft, W. E. (2006), they found that S. aureus isolation rates from septic arthritis were $(60 \% \& 70 \%)$ respectively. This high ratio of Staphylococcus aureus isolation from the specimens of this study may be due to many factors related to this organism like virulence factors of this bacteria, as well as pathogenicity factors such as protein A, coagulase and biofilm formation capacity Brooks, G, F. (2004). Staphylococcus 
epidermidis is opportunistic pathogen causing infection accidentally as in case of septic arthritis in studied patients Mahmoud, D. A. R., (2004). Unfortunately $S$. epidermidis may reach joints due to bad skin disinfection and low precautions during joint centesis and other joint manipulations Sweiss, N. et al.(2009). Infection with gram negative bacteria may be due to long hospitalization, migration from microorganisms of the neighboring infected foci or from bones, haematogenous route, postoperative complications, arthroscopies and therapeutic joint injections Canal, S. T. et al. (1998). Our results were similar to, Le Dantec, L. F. et al. (1996) and Mahmoud, D. A. R. (2004), who found that $35 \%$ cultivation results were gram negative organisms and $65 \%$ of them were gram positive organisms. In spite of the similarity in genera of gram negative bacteria isolated from patients in this study with results of other references like, Caksen, H. et al. (2000).; AlMashhadani S.S. (2003). and Mahmoud, D. A. R. (2004), but different rates of gram negative isolation were found between this study and them. Regarding mixed infection, isolation of $E$ coli and $S$. aureus from the same specimen was logical because they are compatible in their growth and resist the antagonizing effect of each. Shirtliff, E. M. and Mader, J. T. (2002). This observation was also mentioned by (Brusch, 2005), who found $5 \%$ of cases anaerobic due to trauma or abdominal infection. In this study 75 of specimens showed negative cultivation results .This agreed with (Lyon \& Evanich 1994), who found that $70 \%$ of the cases were culture negative. This high rate of negative cultivation results was attributed to either actual absence of infectious agent in synovial fluid, or to the fact that there is true pathogen requiring more microbiological investigation to detect them like Brucella species, Chlamydia, Mycoplasma, Spirochetes and viral infection, Washington et al. (2006). and Brooks, G. F. (2004).

\section{REFERENCES}

Al-Baiatti, H. H. A., (2004). A study on the possible role of some microorganisms in Rheumatoid arthritis. Msc. thesis submitted to the college of medicine
Bacterial infection induces an influx of WBCs at the site of joint infection, Roitt, I. et al. (2001)., this leads to an increase of WBCs counts in synovial fluid of patients with septic arthritis in this study. This was in accordance with (Brusch, 2005). Regarding CRP values in sera of our patients with septic arthritis, they were similar to that of (McCune \& Golbus., 2001).

Increased acute phase proteins like CRP was ought to the effect of IL-6 released from liver, Roitt, I. et al. (2001).; Scott, L. D. and Kingsley, H. G. (2008).

We did not find significant differences among patients groups of this study for different types of arthritis, this confirms CRP as supportive non specific test in this category. Geirsson, J. A. et al. (2008).; Kherani, B. R. and Shojania, K. (2007).

Decreased glucose values in synovial fluid of patients with septic arthritis was due to the glycolytic activities of the white blood cells and utilization of sugar by invading bacteria, Brooks, G, F. et al.(2004). Our findings were in accordance with the findings of (6) who found that glucose levels will be lower in Synovial fluid in comparison to serum sugar values in patients with septic arthritis.

At the same time increased values of protein in Synovial fluid of patients with both types of arthritis was due to leakage of protein through the blood vessels and attracted microbial cells, Cohen, A. S. et al. (1975).

We can conclude from this study that physical and chemical characters are helpful in Synovial fluid manipulation. Staphylococcus aureus and $S$.epidermedis as well as E coli are considered as important pathogens in arthritis $S$. epidermedis could be considered in joint infections in patients with joint implants. Sugar values are useful for the differentiation of septic arthritis form other types of joint affections.

and the committee postgraduate studies of Baghd.

Al-Mashhadani S.S. (2003). Microbiology study of bone and joint infection among Iraqi patients. Msc A thesis submitted to the college of medicine and the committee of post graduate 
studies of Baghdad University. arthritis. [Medscape].

Brooks, G. F.; Butel, J. S. and Morse, S. A. (2004). Medical microbiology . 22 ed, Appleton \& Lange. California . 198213.

Brusch, L. J. (2005). Septic arthritis An article Internet. www. Emedline.com .P:2-13. Internet.

Caksen, H.; Ozturk, M. K.; Uzum, K.; Yuksen, S.; Ustunbas, H. B. and Per, H. (2000). Septic arthritis in childhood .pediatr-cardiol . 42(5): 536-5.

Canal, S. T.; Daugherty, K. and Jones, L. (1998). Campbell's operative orthopedics. 9 edition. 1. 1.5780623: Macgrow-Hill.

Cohen, A. S.; Bradt, K. D. and Krey, P. K. (1975) synovial fluid in laboratory diagnostic procedures. In Cohen, As (ed): The Rheumatic diseases, 2 edition Boston, Little, Brown \& Co.

Dale, C. D. and Federman, D. D. (2003). Scientific American Medicine.Vol. 2 WebMD. Printed in U.S.A. P: 1505, 1509, 1560, 1568.

Davidson, I. and Henry, B. J. (1974). TODD SANFORD Clinical Diagnosis Laboratory Methods. $5^{\text {th }}$ ed. SAUNDERS Publisher London UK. P:1265-1270.

Dickie, A. S. (1986). Current concepts in the management of infections in bones and joints. Drugs 32:458-475.

Dorwart, B. B. and Schumacher, H. R. (1975). Joint effusions chondrocalcinosis and other rheumatic manifestations in hypothyroidism. A clinical pathologic study. Am J Med .59:780-790.

Gaffney, K.; Williams, R. B.; Jolliffe, V. A. and Blake, D. R. (1995). Intraarticular pressure changes in rheumatoid and normal peripheral joints. Ann rheum. Dis. 54:670-673.

Gatter, R. A., (1984). A practical Handbook of joint fluid analysis. Philadelphia : Lea \& Febiger.

Gavet, F.; Tournadre, A.; Soubrier, M.; Ristori, J. M. and Dobust, J. J. (2005). Septic arthritis in patients aged 80 and older. Acomparison with younger adults. J Am Gariatr Soc. 53:1210-13.

Geirsson , J. A.; Statkevicius, S. and Vikingsson. A. (2008). septic arthritis in Iceland 1990-2002 increasing incidence due to iatrogenic infection.
Annals of the Rheumatic Diseases. 67:635-643.

Kherani, B. R. and Shojania, K. (2007). Septic arthritis in patients with pre- existing inflammatory arthritis. Canadian Medical Association 176(11) P: 3-6.

Laurent, R. and Gleeson, R. (2000). Synovial fluid analysis in the investigation of arthritis. [Palms Info Link] P:1-6. Internet.

Le Dantec, L. F.; Maury, R. M.; Flipo, S.; Laskri, B.; Cortet, Duquesnoy, B. and Delcambre. (1996). Peripheral pyogenic arthritis. A study of one hundred seventy-nine cases. Rev. Rheum. Engl.63:103-10.

Livolsi, V. A.; Saul, S. H.; Merino, M. J.; Brooks, J. S. J. and Tomazewski, J. E. (1993). Pathology. 3rd edition.

Mahmoud, D. A. R. (2004). Bacteriological study of infected fractures in Iraqi patients. Msc A thesis submitted to the college of medicine and the committee of post graduate of Baghdad University

McCune, W. J. and Golbus, J. (2001). Monoarticular arthritis. Ruddy, S., Harris, E. D., Sledge, C. B., Kelly, W. N., Kelleys Textbook of rheumatology. 6th ed. Philadelphia: Saunders, 367-77.

Munoz, G. and Raycraft, W. E. (2006). Article Septic arthritis: 1-6. www.emedicine.com . Internet.

Roitt, I.; Brostoff, J. and Male, D. (2001). Immunology. 6th ed. Mosby. Harcourt Publishers. 119-123.

Ryan, M. J.; Kavanagh, R.; Wall, P. G. and Hzelman, B. L. (1997). Bacterial joint infections in England and Wales. Analysis of bacterial isolates over a four year period. Br J Rheumatol. 36:370-373.

Scott, L. D. and Kingsley, H. G. (2008). Inflammatory Arthritis in clinical Practice . Springer- Verlag London. P: 19,20 .

Shirtliff, E. M. and Mader, J. T. (2002). Acute septic arthritis. Clinical Microbiolog Reviews, American Society for Microbiology.15(4): 3-16.

Sweiss, N.; Millstein, E. S.; Primus, G. L.; Utset, T. O.; Curran, J. and Lee, (2009). Aspiration techniques and indications for surgery septic

Vincent, G. M. and Amirault, J. D. (1990). Septic arthritis in the elderly. Clin. Orthop. Relat. Res. 251:241-5. 
Washington et al. (2006). Washington W. Jr., Stephen A. et al 2006:Konemans Color Atlas and Textbook of Diagnostic
Microbiology, sixth ed. LIPPNCOTT WILLIAMS \& WILKINS Publishers, NEW YORK, USA.

\section{ARABIC SUMMARY}

\section{دراسة بكتيرية ومصلية على السائل المفصلي لمرضى التهاب المفصل الخمجى

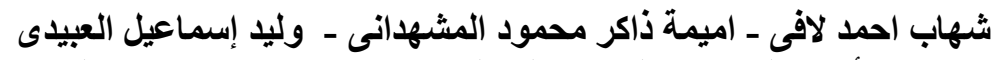

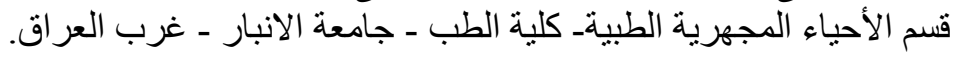

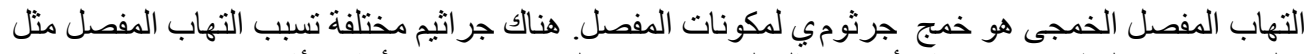

خلفية الدر اسة:

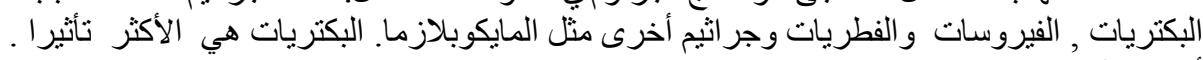

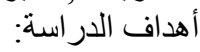

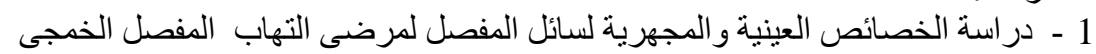

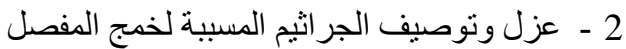

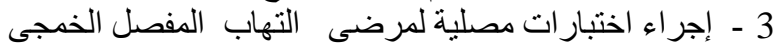

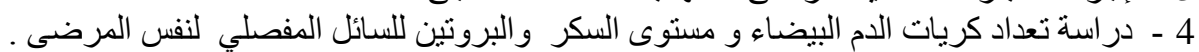

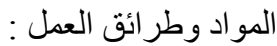

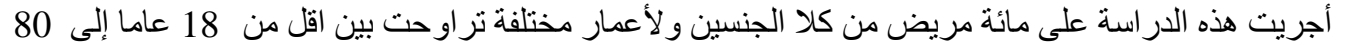

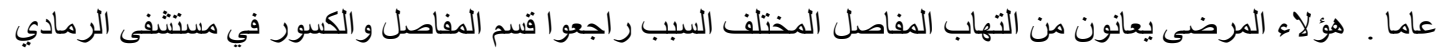

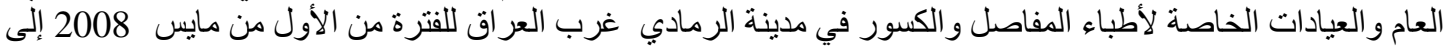

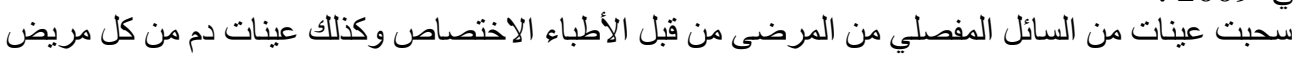
كانون الثاني 2009 .

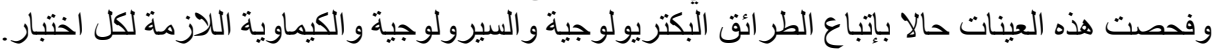
النتائج: وفئ

تبين أن خمسة و عشرين مري ضئا من مجموع مائة مريض كانو ا مصابين بالتهاب المفصل الخمجى بينما كان خمسة

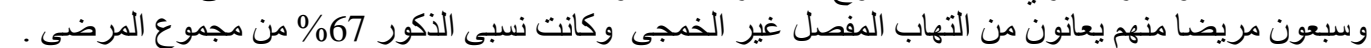

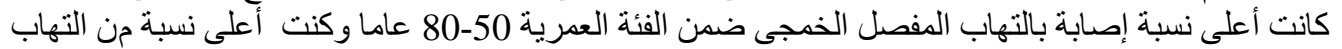

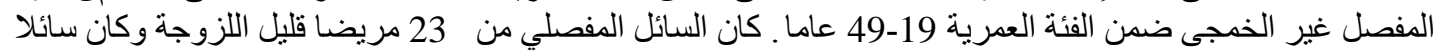

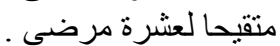

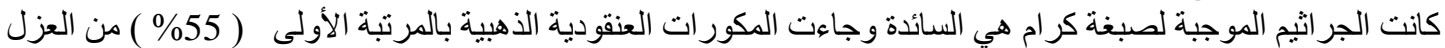

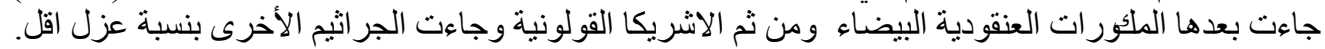

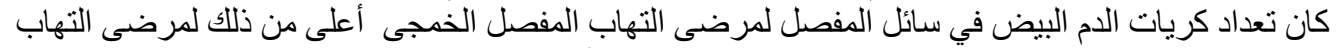

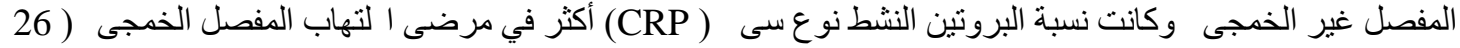

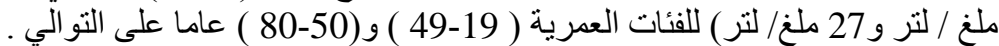

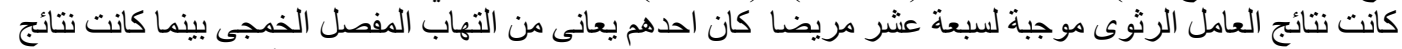

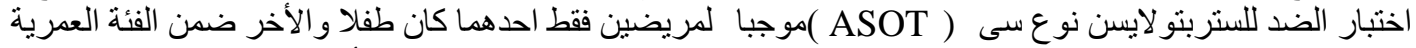

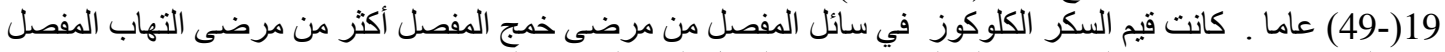

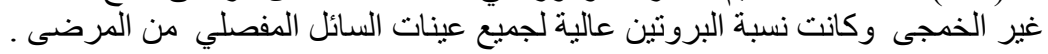

